\title{
Response to X-Irradiation of Fanconi Anemia Homozygous and Heterozygous Cells Assessed by the Single-Cell Gel Electrophoresis (Comet) Assay
}

\author{
Cholpon S. Djuzenova, Andreas Rothfuss, Ulrich Oppitz, Günter Speit, \\ Detlev Schindler, Holger Hoehn, and Michael Flentje \\ Klinik für Strahlentherapie (CSD, UO, MF) and Institut für Humangenetik (DS, HH) der Universität Würzburg, \\ Würzburg, Germany; and Abteilung für Medizinische Genetik (AR, GS), Universitätsklinikum, Ulm, Germany
}

\begin{abstract}
SUMMARY: Fanconi anemia (FA) is an autosomal recessive disorder characterized by bone marrow failure and cancer susceptibility. Patient cells are sensitive to a variety of clastogens, most prominently cross-linking agents. Although there is the long-standing clinical impression of radiosensitivity, in vitro studies have yielded conflicting results. We exposed peripheral blood mononuclear cells from FA patients and carriers to x-rays and determined their DNA damage and repair profiles using the alkaline single-cell gel electrophoresis (comet) assay. Studies were carried out in two independent series of experiments by two laboratories using different protocols. The cells of both FA patients and carriers showed uniformly high initial DNA damage rates as assessed by the total initial tail moment. In addition, the average residual tail moment at 30 to 50 minutes and the repair half-time parameters were significantly elevated. These findings suggest an increased release of fragmented DNA following x-ray exposure in cells that carry one or two mutations in one of the FA genes. The comet assay may be a useful adjunct for heterozygote detection in families of FA patients. (Lab Invest 2001, 81:185-192).
\end{abstract}

$F$ anconi anemia (FA) is a rare autosomal recessive $F$ disorder characterized by diverse developmental abnormalities and progressive bone marrow failure (Buchwald and Moustacchi, 1998). FA patients are prone to develop malignancies, particularly acute myelogenous leukemia and squamous cell carcinomas (Alter, 1996).

The hallmark of the FA cellular phenotype is a high level of spontaneous chromosomal breakage (Schroeder et al, 1964) that is enhanced by exposure of the cells to DNA cross-linking agents such as mitomycin C (Sasaki and Tonomura, 1973) and diepoxybutane (Auerbach and Wolman, 1976). In addition, FA cells have a cell cycle disturbance (Dutrillaux et al, 1982, Kubbies et al, 1985; Seyschab et al, 1995) and increased susceptibility to oxygen-induced damage (Joenje et al, 1981; Schindler and Hoehn, 1988).

A less-known and still controversial feature of FA cells is their radiosensitivity. FA cells were shown to be highly sensitive to $\mathrm{x}$ - or $\gamma$-irradiation (Arlett and Harcourt, 1980; Bigelow et al, 1979; Burnet et al, 1994; Gluckman et al, 1983; Higurashi and Conen, 1971, 1973; Knox et al, 1981; Parshad et al, 1983) and the radiomimetic drug bleomycin (Carreau et al, 1999). On the other hand, irradiated FA primary fibroblasts were found to show the same colony-forming ability as

Received September 28, 2000.

This work was supported by grants of the Deutsche Forschungsgemeinschaft. Address reprint requests to: Prof. Dr. M. Flentje, Klinik für Strablentherapie der Universität Wïrzburg, Josef-Schneider-Strasse 11, D-97080 Würzburg, Germany. E-mail: flentje@strablentherapie.uni-wuerzburg.de irradiated control cells (Duckworth-Rysiecki and Taylor, 1985; Finkelberg et al, 1974; Fornace et al, 1979; Weichselbaum et al, 1980). Likewise, FA peripheral blood lymphocytes displayed similar frequencies of chromosomal aberrations (Natarajan et al, 1984; Sasaki and Tonomura, 1973) as normal cells following $\mathrm{x}$ - or $\gamma$-irradiation.

These conflicting data on radiosensitivity call for a re-examination of the $\mathrm{x}$-ray response of FA cells. We decided to apply the single-cell electrophoresis (comet) assay to this question. To our knowledge, comet assay has not been used before with unstimulated peripheral blood mononuclear cells (PBMCs) from homozygous and heterozygous FA individuals. Under carefully controlled conditions, the alkaline single-cell gel electrophoresis assay (Singh et al, 1988) is widely regarded as a fast and informative method for the assessment of DNA damage (and recovery) at a single-cell level (Olive, 1999). Unlike classical chromosome breakage, micronucleus formation, or cell survival studies, the comet assay measures the production of DNA strand breaks and alkali-labile sites immediately after $\mathrm{x}$-ray exposure and the restoration of high molecular DNA as a function of time after treatment (Olive and Banáth, 1995; Speit and Hartmann, 1999).

\section{Results}

In the Würzburg laboratory, the extent of DNA damage was measured up to 50 minutes after exposure to $\mathrm{x}$-rays with steps of 10 minutes. For each individual, 
the tail moment (TM) data were fitted by a monoexponential function:

$$
\mathrm{TM}(\mathrm{t})=\mathrm{TM}_{0} \cdot \exp \left(-\frac{\mathrm{t} \cdot \ln 2}{\tau_{1 / 2}}\right)+\mathrm{TM}_{\mathrm{R}}
$$

where $t$ is the incubation time after $x$-ray exposure; $\mathrm{TM}_{\mathrm{O}}$ and $\mathrm{TM}_{\mathrm{R}}$ are the initial repairable $\mathrm{TM}$ and residual (ie, irreparable) TM, respectively; $\tau_{1 / 2}$ is the repair half-time, ie, the time required for cells to restore $50 \%$ of the DNA-damage. The total initial $\mathrm{TM}_{\mathrm{IT}}(\mathrm{t} \rightarrow 0)$ is given by the sum: $\mathrm{TM}_{\mathrm{IT}}=\mathrm{TM}_{\mathrm{O}}+\mathrm{TM}_{\mathrm{R}}$. As can be seen from Figure 1, first-order exponential functions provide close approximation to the data points averaged through each group. It is noteworthy that, without $\mathrm{x}$-ray exposure, the TM values for PBMCs from controls and from FA patients and carriers were about 1.2 $\pm 0.3,3.4 \pm 2.9$, and $2.4 \pm 1.3$, respectively. The mean $\mathrm{TM}_{\mathrm{IT}}$ and the mean $\tau_{1 / 2}$ of irradiated cells from FA-heterozygotes were closely similar to, but the mean $\mathrm{TM}_{\mathrm{R}}$ value was 1.5 times lower than, the corresponding values for the FA homozygous cells.

The fitting parameters for each individual, as well as the age, sex, and clinical status, are given in Table 1. The mean $\mathrm{TM}_{\mathrm{IT}}$ values of about 30 (arbitrary units) for the cells from FA patients and heterozygotes were about three times higher than the $\mathrm{TM}_{\mathrm{IT}}$ for the healthy donors $\left(\mathrm{TM}_{\mathrm{IT}} \approx 11, p<0.001\right)$. Except for two false positives (FA-12 and FA-30), there was no overlapping $\mathrm{TM}_{\mathrm{IT}}$-value between FA groups and controls. There-

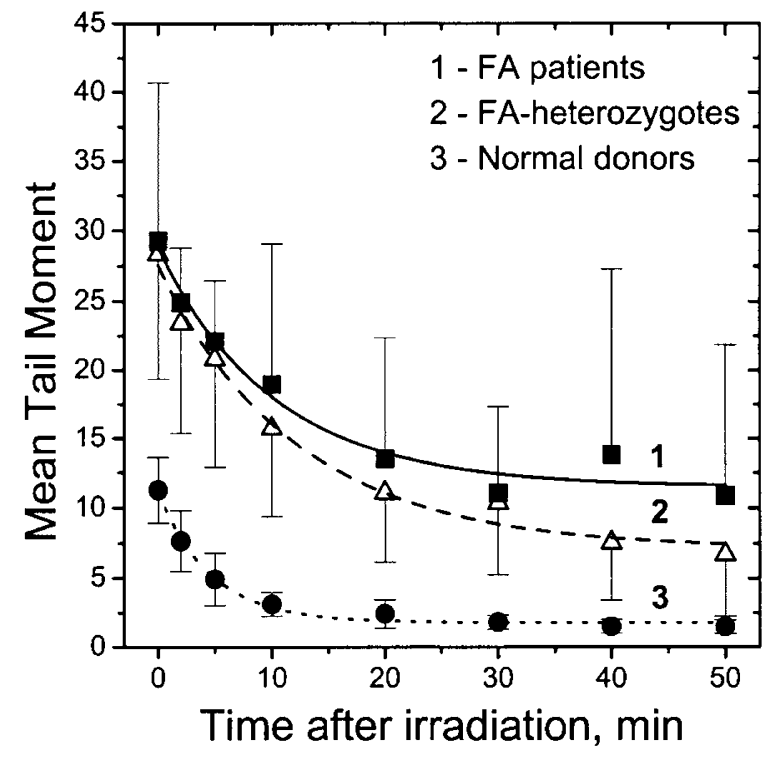

Figure 1.

DNA damage induction and repair profiles measured by the comet assay in human peripheral blood mononuclear cells irradiated with 3 Gy of x-rays in vitro (Würzburg laboratory). The extent of DNA damage was measured quantitatively by the comet tail moment. Cells were isolated from blood of FA patients $(\square, n=8)$, obligate FA-heterozygotes ( $\mathbf{\Delta}, \mathrm{n}=34$ ), and apparently healthy donors $(\boldsymbol{\bullet}, \mathrm{n}=10)$. Immediately after irradiation, the cell samples were placed at $37^{\circ} \mathrm{C}$ in a $5 \% \mathrm{CO}_{2}$ incubator. The cells taken at the indicated time intervals after $\mathrm{x}$-ray exposure were lysed and subjected to the comet assay. One hundred cells were analyzed for each slide. Each point (bar) represents the mean value (SD) of TM for the respective group. The curves are best least-square fits of Equation 1 to the data points. fore, the initial DNA damage in $x$-irradiated cells appears to be the most reliable parameter for the discrimination between controls and FA individuals, both homozygous and heterozygous.

Judging by the DNA-repair half-time $\left(\tau_{1 / 2}\right)$, the repair process in the cells of both FA groups was on average more prolonged than in control cells. Comparison of the repair half-time values reveals 3 overlaps between the FA patients and healthy donors and 21 overlaps between FA-heterozygotes and healthy donors. Nevertheless, the mean $\tau_{1 / 2}$ value of about 10 minutes in the FA patients' and carriers' cells was significantly higher than that in the control cells $(p<0.05)$. Furthermore, the mean residual damage at 50 minutes of about 10 and 7 in the FA homozygous and heterozygous cells, respectively, was significantly higher $(p<0.05$ and $p<0.005$, respectively) than that in the normal donors (mean $\mathrm{TM}_{\mathrm{R}} \approx 2$ ). Damage restoration to control levels was seen only in the cells from one FA homozygote, and in 2 out of the 34 tested heterozygotes. In contrast, the TM values of non-FA cells dropped rapidly during incubation at $37^{\circ} \mathrm{C}$ and reached the level of nonirradiated cells $\left(T_{R} \approx 1\right)$ by 10 minutes (Fig. 1, dotted curve). Representative TM histograms of nonirradiated and irradiated cells, immediately and 50 minutes after x-ray treatment, for normal, FA homozygous, and FA heterozygous cells are shown in Figure 2.

Repeating the experiments with six identical heterozygous donors of the Würzburg series, the UIm laboratory essentially confirmed the observation of a highly significant difference between the initial TM of $\mathrm{x}$-irradiated cells from control and heterozygous individuals (Fig. 3). At 30 minutes after irradiation with 2 Gy, the mean residual TM of heterozygous cells was 2.6 times higher than that of the controls $(p<0.01)$. However, there was no significant difference in the kinetics of damage restoration between the two groups (Fig. 3).

\section{Discussion}

The results we present are highly surprising and unexpected. Whereas it was not completely unexpected that cells from FA patients themselves would show a distinctive behavior after exposure to ionizing radiation and subjection to the comet assay, no such behavior was or could be expected for cells from heterozygous individuals. Although obligate heterozygous individuals from FA families have not been extensively researched, all available evidence suggests that these individuals are free from major clinical symptoms, have a normal life expectancy, and only a minor, if any, elevation of cancer risk (Swift et al, 1980; Petridou and Barrett, 1990; Heim et al, 1992). To convince ourselves of the validity of our observations, we extended the group of heterozygous FA individuals from 10, initially, to a total of 34 donors. We also used another cohort $(n=10)$ of clinically healthy donors, such as that examined previously (Djuzenova et al, 1999). In addition, experiments were performed in two independent series of experiments by two laboratories 
Table 1. DNA Damage Measured by the Comet Assay in PBMCs Isolated from Blood of Apparently Healthy Donors, FA Patients, and Obligate FA Heterozygotes after Exposure to 3 Gy of X-Irradiation In Vitro ${ }^{a}$

\begin{tabular}{|c|c|c|c|c|c|c|}
\hline Subject $^{b}$ & $\begin{array}{c}\text { Age } \\
\text { (years) }\end{array}$ & Sex & $\begin{array}{c}\text { Clinical status } \\
\text { with respect to FA }\end{array}$ & $\begin{array}{c}\text { Total initial TM } \\
\text { TM }_{\text {IT }} \\
\end{array}$ & $\begin{array}{c}\text { Residual TM } \\
\text { TM }_{R}\end{array}$ & $\begin{array}{c}\text { Repair } \\
\text { half-time, } \\
\tau_{1 / 2} \text {, min }\end{array}$ \\
\hline \multicolumn{7}{|c|}{ Apparently healthy donors } \\
\hline D-1 & 39 & M & Healthy & 13.4 & 2.1 & 2.5 \\
\hline D-2 & 20 & M & Healthy & 13.0 & 1.8 & 1.5 \\
\hline D-3 & 44 & $\mathrm{~F}$ & Healthy & 10.5 & 2.1 & 4.0 \\
\hline D-4 & 57 & $\mathrm{~F}$ & Healthy & 8.2 & 2.2 & 9.3 \\
\hline D-5 & 26 & $\mathrm{M}$ & Healthy & 13.3 & 1.0 & 4.3 \\
\hline D-6 & 23 & $\mathrm{~F}$ & Healthy & 14.3 & 1.0 & 4.6 \\
\hline D-7 & 31 & $\mathrm{~F}$ & Healthy & 10.3 & 1.3 & 1.5 \\
\hline D-8 & 49 & M & Healthy & 12.4 & 1.9 & 2.5 \\
\hline D-9 & 26 & $M$ & Healthy & 7.2 & 1.8 & 4.6 \\
\hline$D-10$ & 28 & $\mathrm{M}$ & Healthy & 9.2 & 1.2 & 6.2 \\
\hline Mean & 34 & & & 11.1 & 1.6 & 4.1 \\
\hline $\pm S D$ & 12 & & & 2.4 & 0.5 & 2.4 \\
\hline \multicolumn{7}{|l|}{ FA patients } \\
\hline FA-5 & 9 & $\mathrm{~F}$ & Patient & 54.6 & 27.8 & 0.4 \\
\hline FA-8 & 4 & $\mathrm{~F}$ & Patient & 24.7 & 4.0 & $\overline{12.8}$ \\
\hline FA-11 & 7 & M & Patient & 32.7 & 25.0 & 10.2 \\
\hline FA-12 & 22 & $\mathrm{~F}$ & Patient & 24.0 & 8.0 & 30.0 \\
\hline FA-29 & 19 & $\mathrm{~F}$ & Patient & 26.9 & 5.9 & 4.3 \\
\hline FA-30 & 8 & $\mathrm{~F}$ & Patient & 30.2 & 4.0 & 5.9 \\
\hline FA-33 & 4 & M & Patient & 27.1 & 3.5 & 11.6 \\
\hline FA-34 & 6 & $\mathrm{~F}$ & Patient & 22.3 & 9.0 & 36.3 \\
\hline Mean & 10 & & & 30.7 & 10.2 & 10.4 \\
\hline$\pm \mathrm{SD}$ & 7 & & & 10.1 & 10.1 & 8.9 \\
\hline & & & & $p<0.001$ & $p<0.05$ & $p<0.05$ \\
\hline \multicolumn{7}{|c|}{ FA-heterozygotes } \\
\hline $\mathrm{FA}-1$ & 46 & M & Carrier & 23.5 & 6.3 & 15.4 \\
\hline FA-2 & 54 & $M$ & Carrier & 23.4 & 17.0 & 28.3 \\
\hline FA-3 & 50 & $\mathrm{~F}$ & Carrier & 21.0 & 13.0 & 5.0 \\
\hline FA-4 & 32 & $\mathrm{~F}$ & Carrier & 14.9 & 10.5 & $\overline{0.7}$ \\
\hline FA-6 & 36 & $\mathrm{M}$ & Carrier & 56.2 & 12.7 & 1.9 \\
\hline FA-7 & 30 & $\mathrm{~F}$ & Carrier & 29.3 & 9.0 & $\overline{0.5}$ \\
\hline FA-9 & 40 & M & Carrier & 37.3 & 20.0 & $\overline{5.7}$ \\
\hline FA-10 & 32 & $\mathrm{~F}$ & Carrier & 37.7 & 9.7 & 5.7 \\
\hline FA-13 & 45 & M & Carrier & 29.2 & 1.9 & $\overline{15.5}$ \\
\hline FA-14 & 39 & $\mathrm{~F}$ & Carrier & 16.9 & 3.0 & $\underline{8.2}$ \\
\hline FA-15 & 42 & $\mathrm{M}$ & Carrier & 23.3 & 3.0 & 17.7 \\
\hline FA-16 & 38 & $\mathrm{~F}$ & Carrier & 21.5 & 2.5 & $\underline{6.0}$ \\
\hline FA-17 & 36 & M & Carrier & 35.2 & 8.8 & $\overline{4.3}$ \\
\hline FA-18 & 35 & $\mathrm{~F}$ & Carrier & 24.3 & 4.8 & $\overline{9.5}$ \\
\hline FA-19 & 70 & $\mathrm{~F}$ & Carrier & 18.3 & 3.9 & 3.7 \\
\hline FA-20 & 42 & $\mathrm{M}$ & Carrier & 35.3 & 7.0 & $\overline{3.7}$ \\
\hline FA-21 & 36 & $\mathrm{~F}$ & Carrier & 34.0 & 2.5 & 9.9 \\
\hline FA-22 & 36 & M & Carrier & 26.6 & 9.9 & 3.8 \\
\hline FA-23 & 36 & $\mathrm{~F}$ & Carrier & 24.1 & 7.2 & $\overline{4.0}$ \\
\hline FA-24 & 46 & $\mathrm{~F}$ & Carrier & 20.2 & 9.4 & 3.7 \\
\hline FA-25 & 41 & $\mathrm{M}$ & Carrier & 23.5 & 2.5 & $\overline{14.2}$ \\
\hline FA-26 & 44 & $\mathrm{~F}$ & Carrier & 42.1 & 4.2 & 9.8 \\
\hline FA-27 & 31 & M & Carrier & 23.3 & 3.4 & 12.2 \\
\hline FA-28 & 27 & $\mathrm{~F}$ & Carrier & 27.2 & 6.0 & 8.5 \\
\hline FA-31 & 34 & $M$ & Carrier & 21.8 & 5.3 & 12.0 \\
\hline FA-32 & 35 & $\mathrm{~F}$ & Carrier & 23.5 & 4.0 & 5.6 \\
\hline FA-35 & 27 & $M$ & Carrier & 29.0 & 2.8 & 6.2 \\
\hline
\end{tabular}


Table 1. Continues

\begin{tabular}{|c|c|c|c|c|c|c|}
\hline Subject $^{b}$ & $\begin{array}{c}\text { Age } \\
\text { (years) }\end{array}$ & Sex & $\begin{array}{c}\text { Clinical status } \\
\text { with respect to FA }\end{array}$ & $\begin{array}{c}\text { Total initial TM } \\
\mathrm{TM}_{\mathrm{IT}}\end{array}$ & $\begin{array}{c}\text { Residual TM } \\
\text { TM }_{\mathrm{R}}\end{array}$ & $\begin{array}{c}\text { Repair } \\
\text { half-time, } \\
\tau_{1 / 2} \text {, min }\end{array}$ \\
\hline FA-36 & 30 & $\mathrm{~F}$ & Carrier & 33.5 & 2.0 & 12.4 \\
\hline FA-37 & 43 & M & Carrier & 26.0 & 7.5 & 3.9 \\
\hline FA-38 & 30 & $\mathrm{~F}$ & Carrier & 14.5 & 3.0 & $\overline{33.9}$ \\
\hline FA-39 & 29 & M & Carrier & 43.5 & 10.6 & 6.9 \\
\hline FA-40 & 27 & $\mathrm{~F}$ & Carrier & 50.3 & 10.0 & 12.0 \\
\hline FA-41 & 30 & M & Carrier & 27.3 & 6.2 & 6.1 \\
\hline FA-42 & 30 & $\mathrm{~F}$ & Carrier & 28.8 & 5.0 & $\underline{4.3}$ \\
\hline Mean & 38 & & & 28.5 & 6.8 & 9.8 \\
\hline \multirow[t]{2}{*}{ $\pm S D$} & 9 & & & 9.5 & 4.3 & 7.4 \\
\hline & & & & $p<0.001$ & $p<0.005$ & $p<0.05$ \\
\hline
\end{tabular}

PBMCs, peripheral blood mononuclear cells; M, male; F, female; D, healthy donor; FA, Fanconi anemia; TM, tail moment.

${ }^{a}$ Each indicated DNA damage parameter represents the mean value for the cells from a given individual obtained by curve fitting (as in Fig. 1). Significance was established using Student's $t$-test. $p$ compares the differences between the tested group and apparently healthy individuals. Underlined values indicate the overlapping parameter with normal group.

${ }^{b}$ Case number.

using different protocols. As a result of these combined efforts, we must conclude that under the described conditions cells from obligate FA carriers show a behavior that is distinctive from the control cells used here or those in our study published earlier (Djuzenova et al, 1999), when both are subjected to the comet assay after irradiation with 2 or 3 Gy. In contrast to previous reports on the detection of FA heterozygotes using chromosome breakage or cloning survival (Auerbach and Wolman, 1978; Wunder and Fleischer-Reischmann, 1983), the distinction between carriers and controls seems to be reliable, at least when using the initial TM parameter of the comet assay.

It could be argued that pre-existing DNA damage, as indicated by increased spontaneous chromosome breakage rates in FA, may be responsible for the high initial TM values in patients' and carriers' cells. However, such an interpretation is discouraged by the similar TM of both the FA groups and the controls at a zero radiation dose. This fact would also suggest that the residual TM values of both FA groups could be restored to normal given sufficient time. The higher repair half-time values in the FA groups may simply reflect their excess initial TM over the initial TM of the controls rather than a slower DNA repair. In this context it should be noted that increased levels of residual DNA damage were previously reported for irradiated peripheral blood lymphocytes of breast cancer over-reactors (Alapetite et al, 1999) and patients with thyroid tumors (Leprat et al, 1998).

Although the clear distinction between heterozygotes and controls suggests the high sensitivity of the comet assay, its specificity is drawn into question by the observation of two false positives (FA-12 and FA-30) among the eight patients with clinical suspicion of FA. On the basis of chromosome breakage and cell-cycle analysis (Seyschab et al, 1995), the clinical diagnosis of FA was confirmed in six of the eight patients. One patient (FA-12) had normal mitomycin C sensitivity in both blood cells and fibroblasts, together with a completely normal cell-cycle distribution, such that the diagnosis of FA, even in a mosaic state, could be ruled out according to current standards (Joenje et al, 1998). The other patient (FA-30) who turned out to be a false positive in the comet assay lacked mitomycin C sensitivity and chromosome breakage in her blood cells. Her cell-cycle pattern was commensurate with the diagnosis of (non-FA) aplastic anemia, because there was no evidence of $G_{2}$-phase blockage (data not shown). Although the comet assay has been proposed as an adjunct diagnostic tool in a number of diseases, such as Xeroderma pigmentosum, trichothiodystrophy (Alapetite et al, 1997), hematological malignancies (Bacova et al, 1998), and diabetes (Hannon-Fletcher et al, 2000), under our conditions its specificity was not sufficient to be employed as a primary diagnostic test in the differential diagnosis of bone marrow failure.

The obvious question that arises is whether our results bear on the controversial issue of radiosensitivity in FA cells. As we pointed out in the introduction, a number of reports claim to have shown that FA cells are radiosensitive (Bigelow et al, 1979; Burnet et al, 1994; Carreau et al, 1999; Gluckman et al, 1983; Higurashi and Conen, 1971, 1973; Knox et al, 1981; Parshad et al, 1983), and these claims are supported by clinical observations of poor outcome and increased pigmentation and desquamation of irradiated skin areas in a number of FA patients after preconditioning for bone marrow transplantation (Gluckman et al, 1983; Gluckman, 1990; Vossen, 1984). However, there are a number of reports that fail to find evidence for increased radiosensitivity of FA cells, including the studies by Duckworth-Rysiecki and Taylor (1985), Finkelberg et al (1974), Fornace et al (1979), and Weichselbaum et al (1980), and a forthcoming study from our own laboratory that includes 16 fibroblast strains from 7 different FA complementation groups (Schindler D, unpublished data). Because most posi- 


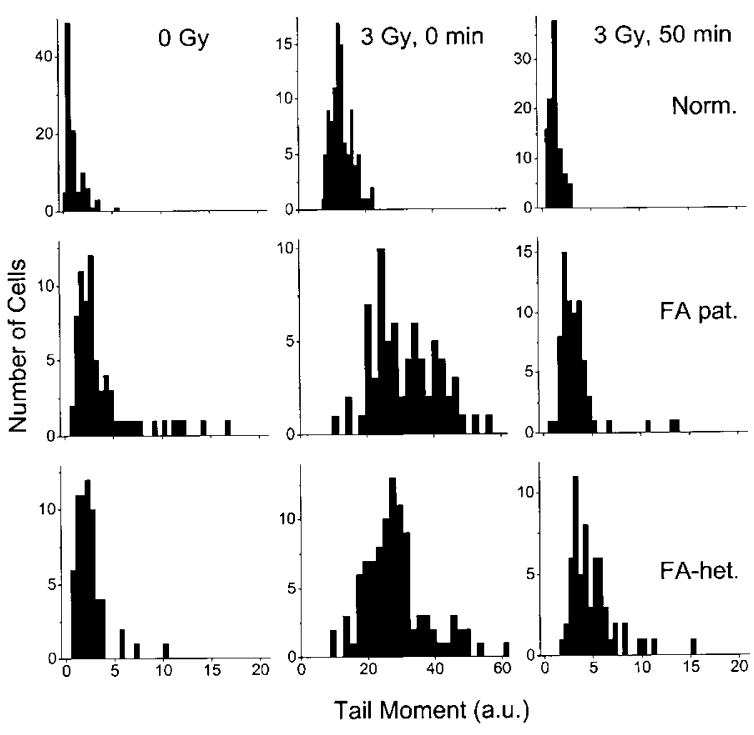

Figure 2.

Representative tail moment distributions of unirradiated (left column) and irradiated PBMCs either immediately (middle column) or 50 minutes (right column) after $x$-ray treatment. Top: Histograms of cells isolated from healthy donor (D-2). Middle and bottom histograms: TM-values of cells from FA homozygote (FA-33) and FA heterozygote (FA-42), respectively.

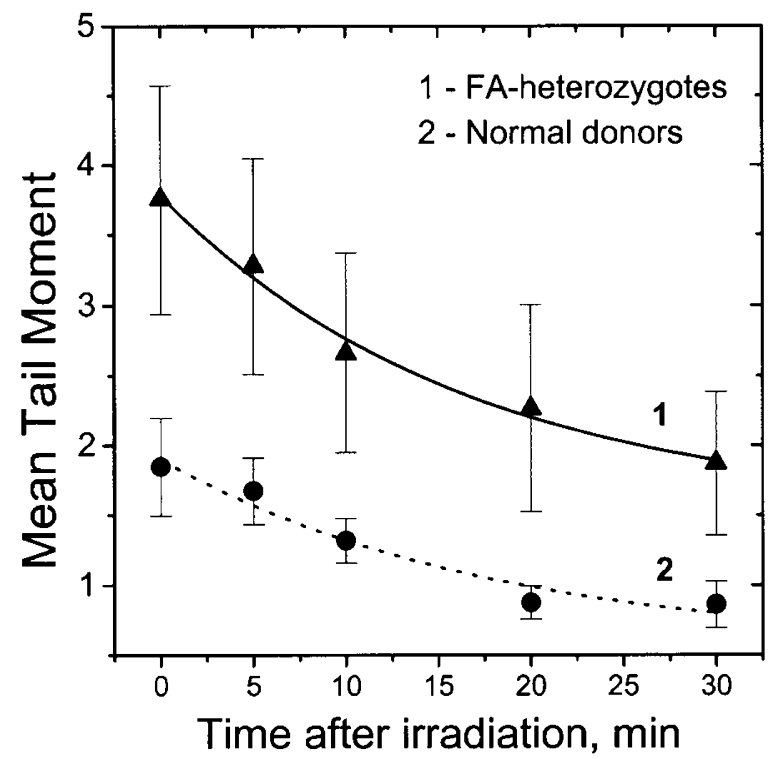

Figure 3.

DNA damage induction and repair profiles measured by the comet assay after whole blood irradiation with 2 Gy of $x$-rays in vitro (Ulm laboratory). The extent of DNA damage was measured quantitatively by the comet tail moment. Heparinized blood was collected from obligate FA-heterozygotes $(\Delta, n=6)$ and apparently healthy donors $(\bullet, n=4)$. Immediately after irradiation on ice, the cell samples were placed at $37^{\circ} \mathrm{C}$ in a $5 \% \mathrm{CO}_{2}$ incubator. The cells taken at the indicated time intervals after $\mathrm{x}$-ray exposure were lysed and subjected to the comet assay. The mean and standard deviations for 100 cells analyzed at random for each slide are shown. The curves are best least-square fits of Equation 1 to the data points.

tive studies employed lymphocytes or lymphoid cell lines, one could argue that mesenchymal cells such as skin fibroblasts respond differently to x-irradiation. Such differences between cell types have in fact been reported in Fanconi anemia, with lymphocytes being more sensitive than fibroblasts (Duckworth-Rysiecki and Taylor, 1985).

In the context of our results, we must emphasize the fact that what is measured by the comet assay is not radiosensitivity in the conventional sense, ie, chromosome breakage, micronucleus formation, reduced growth and cloning survival, or increased mutation frequency. Rather, the comet assay provides a measure of chromatin integrity as a function of time immediately following exposure to a clastogenic agent such as ionizing radiation. Differences in the degree of chromatin compaction may, for example, influence the results of the comet assay (Noz et al, 1996). Moreover, the recognition of DNA damage by means of the comet assay is known to be influenced by a number of factors that would alter the DNA release from the nuclear protein matrix (Speit and Hartmann, 1999). Therefore, pre-existing intrinsic alterations in chromatin conformation might well determine the degree of DNA migration in response to radiation-induced damage (Chiu et al, 1992; Newton et al, 1996; Woudstra et al, 1996). The failure of FA homo- and heterozygous cells to respond normally to $x$-irradiation in the comet assay is consistent with the recent notion that FA might be a "chromatin disease" in which a defective complex of the various FA-proteins does not adequately fulfill its role in chromatin remodeling in situations of cellular stress (Hoatlin et al, 1999; Reuter T, unpublished data).

In summary, we show that cells from FA patients and heterozygotes respond differently to controls when examined by the alkaline comet assay following $x$-irradiation. Whether this property is caused by defects in DNA repair, an altered chromatin structure, abnormalities in oxygen metabolism, and/or other mechanisms remains to be elucidated.

\section{Materials and Methods}

\section{Subjects}

The assay was performed on PBMCs isolated from three different groups of individuals: (a) apparently healthy donors $(n=10)$; (b) patients with the clinical diagnosis of $F A(n=8)$; and (c) a group of obligate FA carriers (parents of individuals with clinically and chromosomally proven $F A, n=34$ ). All subjects or their parents gave informed consent to participate in this study.

\section{Cells}

PBMCs were separated from the heparinized blood samples by density-gradient centrifugation using Ficoll-Histopaque 1077 (Sigma, St. Louis, Missouri) according to the manufacturer's instructions. PBMCs were washed twice with $\mathrm{Ca}^{2+}$ - and $\mathrm{Mg}^{2+}$-free physiological phosphate-buffered saline (Sigma D-8537), finally resuspended in the freezing medium containing RPMI 1640 (Biowhittaker, Verviers, Belgium), 10\% FCS, and $10 \%$ dimethyl sulfoxide, and stored frozen in liquid nitrogen until analysis. 


\section{X-ray Irradiation before Comet Assay}

One to two hours before irradiation, cells were thawed, centrifuged, and resuspended in $1.5 \mathrm{ml}$ of complete growth medium, consisting of RPMI 1640 supplemented with 10\% FCS, 1\% nonessential amino acids, $1 \mathrm{~mm}$ sodium pyruvate, $2 \mathrm{~mm}$ L-glutamine, and penicillin/streptomycin (100 U/ml and $100 \mu \mathrm{g} / \mathrm{ml}$, respectively). The final cell density of PBMCs was adjusted to $1 \times 10^{6} \mathrm{cell} / \mathrm{s} / \mathrm{ml}$ and the samples were placed at $37^{\circ} \mathrm{C}$ in a $5 \% \mathrm{CO}_{2}$ incubator. X-irradiation was performed using a 10 MV Philips x-ray source (Philips, Crowley, United Kingdom) at a dose rate of 4 Gy/ minutes. Precooled cell samples were irradiated in 4-well culture plates (Nunc, Verviers, Denmark) on ice and then allowed to repair the DNA damage by incubation at $37^{\circ} \mathrm{C}$ in a $5 \% \mathrm{CO}_{2}$ incubator. Aliquots of cells were taken at fixed time intervals after the $\mathrm{x}$-ray exposure and then analyzed for DNA damage using the alkaline comet assay. Nonirradiated cells were treated in similar way (but at a zero radiation dose).

\section{Alkaline Comet Assay}

In the Würzburg laboratory, the comet assay was performed following a protocol as previously described (Djuzenova et al, 1999). Dakin fully frosted microscope slides (Richardson Supply Company Ltd., London, United Kingdom) were each covered with 400 $\mu l$ of $0.75 \%$ normal-melting-point agarose (Roth, Karlsruhe, Germany) in PBS prewarmed to $45^{\circ} \mathrm{C}$. A coverglass was placed over the agarose solution, and the agarose was allowed to solidify. The coverglass was then removed, and $85 \mu$ of cell/agarose suspension $\left(10 \mu \mathrm{l}\right.$ of cell suspension containing about $10^{4}$ cells mixed with $75 \mu \mathrm{l}$ of $0.5 \%$ low-melting-point agarose [Roth] in PBS) was placed over the first agarose layer and allowed to solidify under a fresh coverglass. After removing the coverglasses, $100 \mu \mathrm{l}$ of $0.5 \%$ low-melting-point agarose was added and allowed to solidify. After the coverglass was removed, the slides were gently immersed in a cold lysis solution (2.5 M NaCl, 100 mm EDTA, 10 mm Tris, 1\% sodium sarcosinate $[\mathrm{pH}$ adjusted to 10 with $\mathrm{NaOH}$ ], 10\% dimethyl sulfoxide, and 1\% Triton $\mathrm{X}-100$ added just before use) for 1 hour at $4^{\circ} \mathrm{C}$ to lyse the cells and permit DNA unfolding. The microscope slides were transferred to the horizontal gel electrophoresis unit filled with fresh, chilled electrophoresis buffer $(300 \mathrm{~mm}$ $\mathrm{NaOH}, 1 \mathrm{~mm}$ EDTA, $\mathrm{pH}$ 13.5) to a level of about 0.25 $\mathrm{cm}$ above the slides and left for 20 minutes to allow unwinding of DNA before electrophoresis. Electrophoresis was conducted for the next 20 minutes at 25 $\mathrm{V}(1.1 \mathrm{~V} / \mathrm{cm})$. The slides were then drained, placed on a tray, and flooded slowly with three changes of a neutralization buffer $(0.4 \mathrm{M}$ Tris, $\mathrm{pH} 7.5)$, each for 5 minutes, to remove alkali and detergents. The slides were stained with propidium iodide (Sigma, P-4170, $10 \mu \mathrm{g} / \mathrm{ml}$ solution in PBS), $50 \mu \mathrm{l} / \mathrm{slide}$, covered with a coverglass, and placed in a humidified air-tight container to prevent drying of the gel. They were analyzed within 24 hours.

\section{Comet Capture and Analysis}

Propidium iodide-stained electropherograms were examined in an epifluorescent microscope (Leica, Wetzlar, Germany; DMLB, excitation filter: 515-560 nm; barrier filter: $590 \mathrm{~nm}$ ) attached to a black and white CCD video camera (Cohu Electronics, San Diego, California), that was connected to a computer equipped with the image analysis software Komet 3.1 (Kinetic Imaging Ltd., Liverpool, United Kingdom). One hundred randomly captured cells from each slide were analyzed at each sampling time. Superimposed cells and cells on the edge of the gels were avoided. Several features for each cell were evaluated by the software package, but the tail moment (TM) was used here to measure quantitatively the extent of DNA damage. The TM value (given in arbitrary units) is defined as the product of the percentage of DNA in the comet tail and the tail length.

A slightly different protocol was used by the UIm laboratory (Speit and Hartmann, 1999). Main differences consisted in (a) $\gamma$-irradiation and processing of whole blood instead of $\mathrm{x}$-irradiation of isolated mononuclear cells; (b) a reduced radiation dose of only 2 instead of 3 Gy; (c) a shorter incubation period at $37^{\circ} \mathrm{C}$ after irradiation (30 vs 50 minutes); (d) normal slides precoated with agarose; (e) a time of alkali denaturation and electrophoresis $(0.86 \mathrm{~V} / \mathrm{cm})$ of 25 minutes each; and ( $f$ ) a different set-up for the assessment of DNA damage (Perceptive Instruments, Suffolk, United Kingdom).

\section{Statistics}

Data are presented as mean $( \pm \mathrm{SD})$. Mean values were compared by the Student's $t$ test. $p<0.05$ was regarded as statistically significant.

\section{References}

Alapetite C, Benoit A, Moustacchi E, and Sarasin A (1997). The comet assay as a repair test for prenatal diagnosis of Xeroderma pigmentosum and trichothiodystrophy. J Invest Dermatol 108:154-159.

Alapetite C, Thirion P, de la Rochefordiere A, Cosset JM, and Moustacchi E (1999). Analysis by alkaline comet assay of cancer patients with severe reactions to radiotherapy: Defective rejoining of radioinduced DNA strand breaks in lymphocytes of breast cancer patients. Int J Cancer 83:83-90.

Alter BP (1996). Fanconi's anemia and malignancies. Am J Hematol 53:99-110.

Arlett CF and Harcourt SA (1980). Survey of radiosensitivity in a variety of human cell strains. Cancer Res 40:926-932.

Auerbach AD and Wolman SR (1976). Susceptibility of Fanconi's anaemia fibroblasts to chromosome damage by carcinogens. Nature 261:494-496.

Auerbach AD and Wolman SR (1978). Carcinogen-induced chromosome breakage in Fanconi's anaemia heterozygous cells. Nature 271:69-71. 
Bacova G, Gabelova A, Babusikova O, and Slamenova D (1998). The single cell gel electrophoresis: A potential tool for DNA analysis of the patients with hematological malignancies. Neoplasma 45:349-359.

Bigelow SB, Rary JM, and Bender MA (1979). G 2 chromosomal radiosensitivity in Fanconi's anemia. Mutat Res 63: 189-199.

Buchwald M and Moustacchi E (1998). Is Fanconi anemia caused by a defect in the processing of DNA damage? Mutat Res 408:75-90.

Burnet NG, Wurm R, Tait DM, and Peacock JH (1994). Cellular sensitivity and low dose-rate recovery in Fanconi anaemia fibroblasts. $\mathrm{Br} \mathrm{J}$ Radiol 67:579-583.

Carreau M, Alon N, Bosnoyan-Collins L, Joenje H, and Buchwald M (1999). Drug sensitivity spectra in Fanconi anemia lymphoblastoid cell lines of defined complementation groups. Mutat Res 435:103-109.

Chiu SM, Xue LY, Friedman LR, and Oleinick NL (1992). Chromatin compaction and the efficiency of formation of DNA-protein crosslinks in gamma-irradiated mammalian cells. Radiat Res 129:184-191.

Djuzenova CS, Schindler D, Stopper H, Hoehn H, Flentje M, and Oppitz U (1999). Identification of ataxia telangiectasia heterozygotes, a cancer-prone population, using the singlecell gel electrophoresis (comet) assay. Lab Invest 79:699705.

Duckworth-Rysiecki G and Taylor AMR (1985). Effects of ionizing radiation on cells from Fanconi's anemia patients. Cancer Res 45:416-420.

Dutrillaux B, Aurias A, Dutrillaux AM, Buriot D, and Prieur M (1982). The cell cycle of lymphocytes in Fanconi anemia. Hum Genet 62:327-332.

Finkelberg R, Thompson MW, and Siminovitch L (1974). Survival after treatment with EMS, $\gamma$-rays, and mitomycin C of skin fibroblasts from patients with Fanconi's anemia. Am J Hum Genet 26:30A.

Fornace AJ, Little JB, and Weichselbaum RR (1979). DNA repair in Fanconi's anemia fibroblast cell strain. Biochim Biophys Acta 561:99-109.

Gluckman E, Devergie A, and Dutreix J (1983). Radiosensitivity in Fanconi anaemia: Application to the conditioning regimen for bone marrow transplantation. $\mathrm{Br} \mathrm{J}$ Haematol 54:431-440.

Gluckman E (1990). Radiosensitivity in Fanconi anemia: Application to the conditioning for bone marrow transplantation. Radiother Oncol 18:88-93.

Hannon-Fletcher MP, O'Kane MJ, Moles KW, Weatherup C, Barnett CR, and Barnett YA (2000). Levels of peripheral blood cell DNA damage in insulin dependent diabetes mellitus human subjects. Mutat Res 460:53-60.

Heim RA, Lench NJ, and Swift M (1992). Heterozygous manifestations in four autosomal recessive human cancerprone syndromes: Ataxia telangiectasia, xeroderma pigmentosum, Fanconi anemia, and Bloom syndrome. Mutat Res 284:25-36.

Hoatlin ME, Zhi Y, Ball H, Silvey K, Melnick A, Stone S, Arai S, Hawe N, Owen G, Zelent A, and Licht JD (1999). A novel BTB/POZ transcriptional repressor protein interacts with the Fanconi anemia group C protein and PLZF. Blood 94:37373747.
Higurashi M and Conen PE (1971). In vitro chromosomal radiosensitivity in Fanconi's anemia. Blood 38:336-342.

Higurashi M and Conen PE (1973). In vitro chromosomal radiosensitivity in "chromosomal breakage syndromes." Cancer 32:380-383.

Joenje $\mathrm{H}$, Arwert $\mathrm{F}$, Eriksson AW, de Koning $\mathrm{H}$, and Oostra AB (1981). Oxygen-dependence of chromosomal aberrations in Fanconi's anaemia. Nature 290:142-143.

Joenje H, Arwert F, Kwee ML, Madan K, and Hoehn H (1998). Confounding factors in the diagnosis of Fanconi anaemia. Am J Med Genet 79:403-405.

Knox SJ, Wilson FD, Greenberg BR, Shifrine M, Rosenblatt LS, Reeves JD, and Misra H (1981). Increased radiosensitivity of a subpopulation of T-lymphocyte progenitors from patients with Fanconi's anemia. Blood 57:1043-1048.

Kubbies M, Schindler D, Hoehn H, Schinzel A, and Rabinovitch PS (1985). Endogeneous blockage and delay of the chromosome cycle despite normal recruitment and growth phase explain poor proliferation and frequent endomitosis in Fanconi anemia cells. Am J Hum Genet 37:1022-1030.

Leprat F, Alapetite C, Rosselli F, Ridet A, Schlumberger M, Sarasin A, Suarez HG, and Moustacchi E (1998). Impaired DNA repair as assessed by the "comet" assay in patients with thyroid tumors after a history of radiation therapy: A preliminary study. Int J Radiat Oncol Biol Phys 40:10191026.

Natarajan AT, Vossen JMJJ, and van Rijn JLS (1984). Cytogenetic response of Fanconi's anaemia lymphocytes to mitomycin C, X-rays and DNA repair inhibitors. Clin Genet 25:210.

Newton GL, Aguilera JA, Ward JF, and Fahey RC (1996). Polyamine-induced compaction and aggregation of DNA: A major factor in radioprotection of chromatin under physiological conditions. Radiat Res 145:776-780.

Noz KC, Bauwens M, van Buul PP, Vrolijk H, Schothorst AA, Pavel S, Tanke HJ, and Vermeer BJ (1996). Comet assay demonstrates a higher ultraviolet B sensitivity to DNA damage in dysplastic nevus cells than in common melanocytic nevus cells and foreskin melanocytes. J Invest Dermatol 106:1198-1202.

Olive PL (1999). DNA damage and repair in individual cells: Applications of the comet assay in radiobiology. Int $\mathrm{J}$ Radiat Biol 75:395-405.

Olive PL and Banáth JP (1995). Radiation-induced DNA double-strand breaks produced in histone-depleted nuclei measured using the neutral comet assay. Radiat Res 142: $144-152$

Parshad R, Sanford KK, and Jones GM (1983). Chromatid damage after G2 phase x-irradiation of cells from cancerprone individuals implicates deficiency in DNA repair. Proc Natl Acad Sci USA 80:5612-5616.

Petridou M and Barrett AJ (1990). Physical and laboratory characteristics of heterozygote carriers of the Fanconi aplasia gene. Acta Paediatr Scand 79:1069-1074.

Sasaki MS and Tonomura A (1973). A high susceptibility of Fanconi's anemia to chromosome breakage by DNA crosslinking agents. Cancer Res 33:1829-1836.

Schindler D and Hoehn H (1988). Fanconi anemia mutation causes cellular susceptibility to ambient oxygen. Am J Hum Genet 43:429-435. 
Schroeder TM, Anschutz F, and Knopp A (1964). Spontane Chromosomenaberrationen bei familiaeer Panmyelopathie. Humangenetik 1:194-196.

Seyschab H, Friedl R, Sun Y, Schindler D, Hoehn H, Hentze S, and Schroeder-Kurth T (1995). Comparative evaluation of diepoxybutane sensitivity and cell cycle blockage in the diagnosis of Fanconi anemia. Blood 8:2233-2237.

Singh NP, McCoy MT, Tice RR, and Schneider E (1988). A simple technique for quantitation of low levels of DNA damage in individual cells. Exp Cell Res 175:184-191.

Speit $G$ and Hartmann A (1999). The comet assay (single-cell gel test). In: Henderson DS, editor. Methods in molecular biology, vol 113: DNA repair protocols: Eukaryotic systems. Totowa, NJ: Humana Press Inc., 203-212.

Swift M, Caldwell RJ, and Chase C (1980). Reassessment of cancer predisposition of Fanconi anemia heterozygotes. J Natl Cancer Inst 65:863-867.
Vossen JM (1984). Experience with bone marrow transplantation in Fanconi's anemia. Clin Genet 25:209.

Weichselbaum RR, Nove J, and Little JB (1980). X-ray sensitivity of fifty-three human diploid fibroblast cell strains from patients with characterized genetic disorders. Cancer Res 40:920-925.

Woudstra EC, Roesink JM, Rosemann M, Brunsting JF, Driessen C, Orta T, Konings AW, Peacock JH, and Kampinga $\mathrm{HH}$ (1996). Chromatin structure and cellular radiosensitivity: A comparison of two human tumour cell lines. Int $\mathrm{J}$ Radiat Biol 70:693-703.

Wunder E and Fleischer-Reischmann B (1983). Response of lymphocytes from Fanconi's anemia patients and their heterozygous relatives to 8-methoxy-psoralene in a cloning survival test system. Hum Genet 64:167-172. 